Кузьменко О. М., к.е.н., доцент Державний університет інфраструктури та технологій м. Київ, Украӥна

DOI: https://doi.org/10.30525/978-9934-26-064-3-5

\title{
ВПЛИВ ГЛОБАЛЬНИХ ПРОЦЕСІВ НА СВІТОВИЙ РИНОК АВТОМОБІЛІВ
}

Як і більшість промислових товарів, автомобілі вже не $\epsilon$ предметом розкоші, а виступають в більшості випадків лише засобом пересування. Стрімкий розвиток інфраструктури 3 середини 40-50 pp. ХХ століття, в тому числі і автомобільних доріг, призвів до значного зростання чисельності автомобілів у світі, а національні автомобільні виробники перетворилися на великі міжнародні промислові автомобільні корпорації, які в окремих країнах є системно утворюючими суб'єктами глобального бізнесу. Все це вказує на потребу аналізу специфіки еволюції світового автомобільного ринку. Світовий ринок автомобілів $є$ доволі динамічним та мало консервативним в результаті проведення активних інноваційних заходів та постійного впровадження результатів науково-дослідних та дослідно-конструкторських робіт (НДДКР).

Розвиток світової економіки протягом останніх 100 років зазнав стратегічних змін від економічної ізоляції до відкритості ринків та лібералізації торгівлі і створення умов для вільного руху товарів, послуг, капіталу, трудових ресурсів, що було 
зумовлено динамічним розвиток соціально-трудових та економічно-інтеграційних трендів після 40-60-х років XX століття. Дана економічна трансформація була зумовлена економічною глобалізацією. На ринку автомобілебудування глобалізація має наступні види впливу на економічну систему:

- світова спеціалізація окремих держав та компаній на випуску автомобілів;

- активне впровадження НДДКР для функціонального покращення автомобілів;

- реалізація екологічних стандартів;

- наближення виробників до споживачів автомобілів;

- впровадження агресивного маркетингу та якісного сервісу як елементів отримання додаткових глобальних конкурентних переваг для виробників авто;

- вплив брендингу на стратегію ціноутворення світових автомобільних виробників;

- активне впровадження інновацій для скорочення споживання палива та підвищення функціонального рівня авто на глобальних товарних ринках;

- значні логістичні канали постачання продукції (авто) до кінцевих споживачів [1].

Сучасний міжнародний ринок автомобілебудування залежить від наступних трендів: - падіння рівня ділової активності на товарних та сировинних ринках;

- активне впровадження НДДКР в високотехнологічні галузі (в тому числі й в автомобілебудування);

- залежність від цін на сировину та супутні товари (паливо, енергія);

- екологічний тренд стимулює розробку НДДКР в сфері ємності електробатарей електромобілів;

- високорозвинені країни стимулюють за рахунок податкових та адміністративних методів використання автомобілів 3 меншим обсягом двигуна, електромобілів або альтернативних засобів пересування (велосипедів, електромопедів, скутерів тощо) [3]. 
Автомобільна екосистема ЄС забезпечує роботу 14,6 млн. жителів ЄС, що становить $6,7 \%$ загальної зайнятості. Оскільки 2,7 млн. осіб працюють на виробництві автомобілів на 226 заводах в СС, на автомобільну промисловість припадає 8,5\% від загальної кількості виробничих робочих місць в європейському регіоні. Понад 18,5 млн. автомобілів було «зроблено в Європі» у 2019 р., що становить 20\% світового виробництва автомобілів. 5,6 млн. автомобілів було експортовано по всьому світу в 2019 р., що призвело до профіциту торгівлі для ЄС у розмірі 74 млрд. євро. На сьогоднішній день на дорогах Європи перебуває 313 млн. транспортних засобів. Окрім того сектор забезпечує податкові надходження в обсязі понад 440,4 млрд. євро.

Інновації - це основа сучасного автомобільного сектору. Дійсно, автомобільна промисловість на сьогоднішній день $€$ найбільшим джерелом фінансування на НДДКР в СС, інвестуючи 60,9 млрд. євро. СС за цим показником випереджає інші регіони світу у глобальній конкуренції та допомагає втілити екологічно чисту та розумну трансформацію мобільності в реальність. Тож не дивно, що ЄС лідирує у світі, коли йдеться про патенти на самокеровані транспортні засоби, відповідальні за третину глобальних заявок [4].

Сучасний ринок автомобілів досить динамічний. Ключовими трендами розвитку світового ринку автомобілів в умовах макроекономічної турбулентності $€$ вплив карантину від коронавірусу на виробничі системи Китаю, США, СС та інших країн світу, збільшення вимог до екологічної безпеки, зростання популярності електрокарів тощо.

Найбільшим негативним фактором впливу на випуск автомобілів в СC в 2020 році мала пандемія COVID-19. Її вплив на автомобільну промисловість в $€ С$ безпрецедентним i негативним. Більшості виробників автомобілів в ЄС довелося закрити свої локальні виробництва на кілька тижнів і місяців 2020 р. Хоча точні наслідки COVID-19 для фінансових результатів автомобільних європейських виробників за 2020 р. досі 
невідомі, статистика за 3 квартали 2020 року свідчать про вплив COVID-19 на виробництво та зайнятість автомобілів на піку кризи в СС [2].

Зупинення заводів у період карантинних обмежень обумовили скорочення понад 1,1 млн. робочих місць в автомобільній промисловості. При цьому виробничі втрати для всього СС склали понад 2,4 млн. автомобільних засобів лише в пікові кризові місяці в березні-травні 2020 р.; що становить 13\% від загального виробництва в 2019 р. Понад 40\% всіх інфікованих COVID-19 на автомобільних виробництвах перебували в ФРН (569 тис. робітників в ФРН з 1139 тис. робітників в СС загалом).

Сучасним трендом розвитку автомобільної промисловості в ЄС є розробки та випуск електромобілів. Сьогодні стимули для автомобілів з електричною платою доступні в 26 із 27 країн ЄС. Більшість країн-членів ЄС пропонують покупцям електромобілів цілий ряд заохочень, зокрема: бонусні виплати або премії. В таких країнах СC, як Бельгія, Болгарія, Кіпр, Данія, Латвія та Мальта інструменти стимулювання придбання електрокарів мають форму зниження податків та пільг для власників електричних автомобілів. Податки на транспортні засоби, дороги та пальне приносять мільярди євро доходів урядам в $\mathrm{CC}$, допомагаючи фінансувати як інфраструктуру, так і відкриваючи шлях для розвитку неавтоматичних проектів. Обсяг податкових надходжень лише на основних європейських ринках щороку складає 440,4 млрд. євро (країни-члени ЄС-14 та Велика Британія) або більше, ніж у два 3 половиною рази більше загального бюджету СС [3].

Однак, як i раніше, існує велика різниця як в основі оподаткування, так і в рівнях оподаткування в Європейському Союзі. Кілька держав-членів оподатковують автомобілі 3 урахуванням їх потужності, ціни, ваги, ємності циліндрів або поєднання цих факторів, хоча все частіше країни застосовують оподаткування на основі СО2. Сьогодні 24 країни ЄС стягують автомобільні податки частково або повністю на основі викидів $\mathrm{CO} 2$ та/або споживання пального транспортного засобу. 
Трьома країнами, які не застосовують оподаткування на основі $\mathrm{CO} 2$, є Естонія, Литва та Польща. Деякі країни все ще оподатковують автомобілі з урахуванням їх потужності, ціни, ваги, ємності циліндрів або поєднання цих факторів.

Автомобільна промисловість ЄС виступає за гармонізацію податків як необхідну складову внутрішнього ринку. Однак гармонізоване оподаткування повинно в ЄС бути нейтральним між транспортними засобами, орієнтуючись на споживання енергії, СО2 та викиди. Це перший необхідний етап, перш ніж стане можливим створення єдиного європейського ринку транспорту та енергетики.

Всі країни - ринку електромобілів менше $1 \%$ - це половина всіх країн-членів СС - мають ВВП на душу населення менше 29000 євро. Це спостерігалося у ряді південних країн - таких як Іспанія, Італія та Греція - а також у країнах Центральної та Східної Свропи, таких як Литва, Болгарія та Словаччина. Польща має найнижчий рівень споживання електричних автомобілів в ЄC, частка ринку електромобілів становить лише 0,2\%. Навпаки, частка електромобілів понад 3,5\% спостерігається лише в країнах iз ВВП понад 42000 євро, таких як Фінляндія, Нідерланди та Швеція. Нещодавно установи $\mathrm{CC}$ затвердили нову норму $\mathrm{CO} 2$ щодо пасажирських автомобілів, встановивши цільові показники скорочення - 15\% та - 37,5\% на 2025 та 2030 рр. відповідно. Ці цілі будуть випливати з напрямку скорочення показника до рівня 95 г СО2 / км на 2021 р., встановленої в 2013 р. [4].

Продажі електричних та інших автомобілів, що працюють на альтернативному приводі, доведеться збільшувати, якщо рівень CO2 буде досягнуто. Однак, на жаль, у 2018 р. лише 2\% усіх нових легкових автомобілів, зареєстрованих по всьому $\mathrm{CC}$, були електричними. Окрім інвестицій у зарядну інфраструктуру, європейські уряди повинні запровадити значущі та стійкі стимули, щоб заохотити більшу кількість споживачів перейти на електрокари. Люди по всьому СС повинні мати можливість придбати електромобіль - незалежно від того, в якій країні вони живуть. Доступність найновіших технологій з низьким та 
нульовим рівнем викидів має бути вирішена урядами у першочерговому порядку. Хоча фіскальні заходи для стимулювання продажу електромобілів доступні майже у всіх державах ЄC, характер та грошова вартість цих пільг коливається в широких межах. Дійсно, хоча більшість країн надають прості зниження податків або пільги для електричних автомобілів, лише 12 країн-членів ЄС пропонують премії або бонусні виплати покупцям цих автомобілів [4].

Отже, виробники транспортних засобів в $Є С є$ рушійною силою для інновацій у Європі, які проводять наукові дослідження та розробку до більш безпечних, чистих автомобілів, а також покращують виробничі процеси, логістику та управління. Сучасне якісне дорожнє покриття та ефективні транспортні засоби в СС - прямий результат минулих інвестицій у НДДКР. Вони також є доказом інновацій та навичок, що характеризують висококонкурентний європейський автомобільний сектор. Європа має лідерство у світі за патентами на самокеровані транспортні засоби, на що припадає 33,3\% усіх заявок, хоча нестабільність ринку та поява нових конкурентів в 2020 році посилилася негативним впливом пандеміі.

\section{Література:}

1. UNCTAD: Unctad [online] United Nations Conference on Trade and Development. URL: http://unctadstat.unctad.org/wds/ReportFolders/reportFolders. aspx?sCS_Chosen Lang=en

2. Economic and Market Report EU Automotive Industry Full-year 2019. URL: https://www.acea.be/uploads/statistic_documents/Economic_and_Market_Report_full -year_2019.pdf

3. International Organization of Motor Vehicle Manufacturers.OICA is the voice speaking on automotive issues in world. URL: http://www.oica.net/category/mediacenter

4. Passenger car market in Europe - statistics \& facts. URL: https://www.statista.com/topics/6628/passenger-car-market-in-europe 